Arab World English Journal (AWEJ) Volume 12. Number2 June 2021

DOI: https://dx.doi.org/10.24093/awej/vol12no2.33

Pp.479-495

\title{
English Linguistic Competencies Formation through Specially Designed Border Guards' Practical Training
}

\author{
Maiia Karpushyna \\ Foreign Languages Department, \\ Bohdan Khmelnytskyi National Academy of State Border Guard Service of Ukraine, \\ Khmelnytskyi, Ukraine \\ Ihor Bloshchynskyi \\ Foreign Languages Department, \\ Bohdan Khmelnytskyi National Academy of State Border Guard Service of Ukraine, \\ Khmelnytskyi, Ukraine \\ Ivanna Shumylo \\ Foreign Languages Department, \\ Bohdan Khmelnytskyi National Academy of State Border Guard Service of Ukraine, \\ Khmelnytskyi, Ukraine

\section{Ilona Isaieva} \\ Foreign Languages Department, \\ Bohdan Khmelnytskyi National Academy of State Border Guard Service of Ukraine \\ Khmelnytskyi, Ukraine \\ Olha Mysechko \\ Foreign Languages Department, \\ Bohdan Khmelnytskyi National Academy of State Border Guard Service of Ukraine \\ Khmelnytskyi, Ukraine
}

Received: $2 / 12 / 2021$

Accepted: 6/20/2021

Published: 6/28/2021

\section{Abstract}

The current study inquires about the cadets' practical training in their primary positions as interpreters/translators. The research is focused on efficient on-the-job training and its organizational procedures for the competence and competency-based approaches. The aim of the practical training of the cadets who study by Philology specialty is to apply English as a foreign language in service situations concerning language immersion and translating issues in the law-enforcement sphere. Needs analysis conducted by the Foreign Languages Department instructors testified to the great significance of the on-the-job training. The Academy's graduates were interviewed to specify the duties and skills required for their job performance and reveal the gaps in the academic study of the cadets by Philology specialty. For this reason, practical training in linguistics was developed to bring theory and practice together, to improve and foreground the theoretical knowledge through true-to-life task completion. Competencies analysis was made concerning higher education standards by specialty 035 Philology for the first (Bachelor's) level of higher education established by the Ministry of Education and Science of Ukraine, and the relevant ones were selected. Twenty-two cadets of the Academy have undergone practical training in their would-be primary positions. It is expected that the cadets will be provided with relevant experience in the position of an interpreter/translator of the Division of International Cooperation and Border Representative Work and get essential links to the content of the future service. The consequent research will concern the practical training results verification based on their defense presentation assessment.

Keywords: border guard, linguistic competency, practical training, professional competence, interpreter/translator Cite as: Karpushyna, M., Bloshchynskyi,I., Shumylo ,I., Isaieva, I.,\& Mysechko, O. (2021). English Linguistic Competencies Formation through Specially Designed Border Guards' Practical Training. Arab World English Journal, 12 (2) 479-495. DOI: https://dx.doi.org/10.24093/awej/vol12no2.33 


\section{Introduction}

Studying the theory of learning, as well as mastering the skills of its creative use in practice, is almost the main key to specialists' effective training in any field, and future border guards are no exception. Therefore, among many didactic principles that determine the content, organizational forms, and methods of the educational process in harmony with its general goals and laws, almost the first is the principle of connecting theory and practice. The learning process should encourage students to test and apply their knowledge in practice, analyze and transform the surrounding reality, use the surrounding reality both as a source of knowledge and a branch of their practical use, and gain their first insight necessary to understand the core attributes of their future career. When it comes to the linguistic competencies formation using problem-based as well as research- based tasks, properly designed practical training should be an effective means of connecting theory and practice. For the simple reason that it best demonstrates the feasibility of the theory, the mechanism of its application, and adjusts the theory of learning. The effectiveness of the formation of linguistic competencies depend on the cadets' involvement in problem-based interactive learning that is determined by the content, types, forms, and focus of the latter on the features of the future career. On the plus side, the effectiveness of connecting training and practice depends on the content of education, the organization of the educational process, the forms and methods of training used, the time allocated for practical training directly in the Divisions of International Cooperation and Border Representative Work (DICBRW). The more cadets are involved in practical training, the more effective their knowledge is. In precisely this way, knowledge interacts with life. Therefore, the faculty tries to combine cadets' academic activity with practical training, in the process of which up to $85 \%$ of knowledge is absorbed.

Consequently, the academic staff of the Foreign Languages Department worked out the program that specified the organizing procedures of the practical training, including the responsible persons, the competencies to be acquired, the results expected, individual tasks, and the format of their training defense report and evaluation criteria.

English linguistic competency can be defined as the ability to function in true-to-life professionally related communication, including oral and written speech in the line of duty wherever it is required. It makes sense that linguistic competencies must correspond to the professional environment of future border guards. The linguistic competencies of future border guards suggest their ability to provide readily available, culturally appropriate oral and written language services as trained and qualified interpreters/translators in the law-enforcement field. Border guards' career, more than other professions, requires broad knowledge in many areas, including legal issues, environmental problems, travel documents, world nations, and their cultures, and at least one foreign language.

Globalization's impact on the border guard service is critical, as has been attested by an influx of migrants, international businesses, and tourism recently. Therefore, present-day service requires border guards to be skilled in performing complex tasks in an efficient, vigilant, and cost-effective manner. Knowing a foreign language is often a key to find solutions to a problem.

The purpose of the study is to determine the competencies and learning outcomes that cadets should master during practical training as an interpreter/translator of the DICBRW of the 
border guard detachment, as well as the curriculum-stipulated practice results and would-be shortfalls.

The purpose of the study presupposes the following objectives:

Develop a syllabus for practical training of the third year cadets of Bohdan Khmelnytskyi National Academy of the State Border Guard Service of Ukraine - applicants of the first (Bachelor's) level of Higher Education, by specialty 035 Philology following the Instructions for organizing and conducting practical training for the cadets of Bohdan Khmelnytskyi National Academy of the State Border Guard Service of Ukraine (NASBGS);

Study and cover of organizational measures concerning practical training of NASBGS cadets by specialty 035 Philology;

Develop individual tasks for cadets and instructions on practical training results presentations.

Subsequently, this research is minded to contribute to the existing literature on the subject by answering such questions:

What are the linguistic competencies to be formed through practicing English in their primary positions as interpreters/translators?

What learning outcomes do cadets have to demonstrate after passing training?

\section{Literature Review}

The modern labor market requires a higher educational institution (university) graduate to be able to use the acquired theoretical knowledge in non-standard situations and situations that are constantly changing. There is a kind of transition from society, in which knowledge is preferred, to one consisting of life-competent citizens. Therefore, the competence and competency-based approach to the provision of educational services in higher education institutions is still relevant and entails the coordination of the content of education and educational technologies with modern needs. It means systematic analysis of the situation at the border and the adjustment of the content of academic subjects following modern requirements of professional activity and the orientation of the syllabuses to the competence and competencybased approach and what is more is the creation of effective mechanisms for its implementation (Omar, et al., 2008).

Nowadays, there is a need to turn to the latest world achievements in the field of the English language. Some scholars revealed the significance of the English language in the selfeducation of the students of socio-humanitarian specialties. They validated the influence of the English language knowledge on the effectiveness of future specialists' self-education in the process of fundamentalization of academic learning (Melnychuk, Rebukha, Zavgorodnia \& Bloshchynskyi, 2018). The significance of information and communication technologies usage, namely Anki program during the border guard cadets' foreign language professional training for state examinations was revealed in the study of Bloshchynskyi (2017). 
Other scholars described the use of electronic educational and methodological software packages for improving the preparation of the future border guard officers specializing in Philology (humanities branch) for the first (Bachelor's) level of higher education for final examinations (Bloshchynskyi, Halus, Pochekalin \& Taushan, 2018). The recent relevant study (Karpushyna et al., 2019) gives credence to content-based warming-ups in the English class. The cadets by "Law" specialty at Bohdan Khmelnytskyi National Academy of the State Border Guard Service of Ukraine were provided with real-life contexts and settings, and therefore, with adaptable and transferrable skills that they could apply in all areas of the academic and professional life. Interviewing travelers or impostors on the border are among others. The researchers experimented with the interviews based on quasi-professional communication with the second-year cadets employing adopted the NATO Standardization Agreement (STANAG 6001) table of language proficiency levels specifically for the future border guards' language requirements.

Such scholars as I. Melnychuk et al. (2019) revealed the organization of distance learning in the English language by "Nursing" specialty. The study included purpose, tasks, grounds (principles), kinds, forms of distance learning courses taught in English, revealed the reasons for choosing the before-mentioned form of study, and provided organizational, methodological, system, and technical support.

Any practical training can offer indispensable opportunities to learners and introduce them not only to "real life" situations but also to professionals and practitioners. Theall (2012) states that there are many reasons for incorporating real-life situations into the process of education. Many researchers claim that using PBL makes curriculum content relevant as PBL helps focus learning on core information and foster the development of valuable transferrable skills (Ceker, \& Ozdamli, 2016; Karpushyna, 2018; Tang, et all., 2020). In addition, the reason for that is evident- professional activity involves different problems that have to be solved by employees: young or experienced. In their days, Makarenko (1973) and Sukhomlinskii (1963) considered labor activity to be a core activity in students' acquisition of professional and life experience. The latter argued that true happiness goes to those who start their working life with the beginning of their studies, and Makarenko claimed that participation in production is irreplaceably crucial. Montessori (2019) stimulated the professional interests of students in the educational process. Their ideas have not yet lost their significance.

Language practice is an integral component of the professional training of cadets studying by the Philology specialty and allows them to gain knowledge and skills required by their future careers.

\section{Theoretical Analysis of the Problem General Statements}

Practical training has always been an integral part of the educational process at the National Academy of SBGS. As part of the future border guards' training, the Academy widely uses various forms and types of practice, which allows cadets to become effective specialists in border protection issues during their training. However, until now, cadets studying by specialty 035 Philology did not have a philological-oriented practice. Cadets were sent to border guard detachments for practical training on border control and border surveillance issues. This time, 
cadets will be able to apply theoretical knowledge of a foreign language and foreign language skills in real service situations, acquire professional communication skills, make independent decisions based on a specific service situation, and cooperate with border guards of neighboring states using FRONTEX official language - English.

The goal of this practical training is to acquire practical skills while performing the duties of an interpreter/translator of the DICBRW, to study and consolidate knowledge of translation of letters, telegrams, facsimiles, and other documents that come to the border guard detachment from neighboring states, as well as written and oral translation from a foreign language into Ukrainian and vice versa during border-representative meetings, international cooperation events at all levels of the border-representative apparatus of Ukraine, to deepen and re-enforce theoretical knowledge, and therethrough to improve sociolinguistic, cultural, acmeological and translation skills and abilities acquired during the their study at the National Academy.

Thus, the practical training is to involve performing the following tasks:

Systematization, extension, and consolidation of the acquired knowledge and practical skills by specialty 035 Philology;

Gaining skills to assess independently and correctly the situation by the service duties and make informed decisions;

Development of the ability to quickly navigate the state of affairs, problems related to the implementation of control over the accuracy of the translation, which is carried out by an interpreter/translator of a neighboring state during border-representative meetings or international cooperation events;

Acquisition of practical skills in the position of an interpreter/translator of the DICBRW;

Advancing translation memory, speech reactivity, psychological stability, sociability, decency, and the ability to "switch" from one language to another as quickly as possible without any delay;

Development of such moral qualities of an interpreter/translator of the DICBRW: moral will (ability to achieve goals, win the respect of people, self-control); professional dignity (administrational demands, commitment to work); collectivism (organization, sociability); courage (ability to overcome personal and official failures); integrity (respect for the opinions of others, the ability to stand one's ground, etc.);

Improvement of skills in organizing and conducting measures to promptly communicate to concerned officials of the border guard detachment the content of letters, telegrams, facsimile messages, and other documents received by the border guard detachment from neighboring states;

Authentication of protocols drawn up based on the results of border representative meetings in the sector of responsibility of the border guard detachment;

Continuous improvement of their professional level, practicing knowledge of foreign languages demanded by the position; 
Study and ongoing improvement of the level of proficiency in the languages of neighboring states and other languages, which allow them to communicate with representatives of other states, use their knowledge of languages while performing service activities;

Performing written and oral translation within the limits of their service duties.

\section{Organizational Measures of Practical Training}

The practical training program regulates all issues related to the practice. The DICBRW of the border guard detachment has been chosen as a base of practical training on the ground that it meets the following requirements: compliance with the specialty and type of practice, the field of activity provided for in the program, the availability of qualified personnel to guide the cadets' training.

Two months before the practical training starts, the National Academy sends proposals to the division of professional training and organization of educational activities of the Personnel Department regarding the number of cadets and the list of practical training positions, as well as the terms of its implementation.

The organization of practical training is assigned to the Rector of the National Academy. A month before the practical training starts, based on the State Border Guard Service Administration Decree, the Rector issues the Order On the organization of cadets' practical training. The Order stipulates measures enabling the service placement and positions for the cadets; appoints the head of practical training from the academy (if necessary); sets tasks concerning their duties; specifies the inspection tools, the format of final reports, and the membership of the experts' commission for evaluating after-training results.

The field-oriented department in specialty 035 Philology is the Foreign Languages Department. The academic teaching team develops a program of practical training, educational and methodological materials, taking into account the requirements of the Rector's Order. The Faculty of Operational and Service Support, as well as the Foreign Languages Department, develop the training realization plan that has to be approved by the Deputy Rector for Academic Affairs. The plan reflects the preparatory period procedures, training activity progress, and the scheme of the on-the-job practice results.

Within the framework of the preparatory period, cadets study the program of practical training; and the Head of the Faculty of Operational and Service Support prepares and submits relevant applications and certificates on practical training logistics.

Following the schedule, the Head of the Faculty and the Head of the Foreign Languages Department conduct instructor-methodical classes with the personnel, carry out organizational measures concerning security measures, mission statement, paperwork, etc.

Before starting practical training, the cadets study their duties and draw up individual plans for the Training (Table one), further approved by the Head of the state border protection body and agreed by the Division and National Academy supervisors. 
Arab World English Journal (AWEJ) Volume 12. Number 2. June 2021

English Linguistic Competencies Formation

Karpushyna, Bloshchynskyi, Shumylo, Isaieva, \& Mysechko

Table 1. Sample of an individual practical training plan

INDIVIDUAL PLAN

of the practical training

cadet of the course

(first and last name)

who is undertaking practical training in

(name of the division)

in the period from to 20

\begin{tabular}{|c|c|c|}
\hline$\#$ & Planned events & Note \\
\hline 1 & & \\
\hline 2 & & \\
\hline 3 & & \\
\hline
\end{tabular}

Cadet

(name of the academic group)

(military rank) (signature) (first and last name)

20

Cadets' practical training is carried out on the State Border Protection bodies' facilities, which are determined after early approval with the Department of Personnel Professional Training and Education, in a position of an interpreter/translator of the DICBRW of the border guard detachment, for thirty days.

During their practical training cadets

- $\quad$ Acquire skills in performing the duties foreseen by the position of the practical training;

- $\quad$ Adhere to the daily routine established in the division and other requirements of the command papers;

- $\quad$ Perform service duties in the position where they undertake practical training and tasks following the training program and their plans;

- $\quad$ Study the specific nature of service in different conditions;

- $\quad$ Systematically collect and summarize the materials specified in the program.

At the end of practical training, cadets of Bohdan Khmelnytskyi National Academy of the State Border Guard Service of Ukraine draw up written reports on the results of practical training according to the established sample (Table two).

Table 2. Sample report on the results of practical training by a cadet of Bohdan Khmelnytskyi National Academy of the State Border Guard Service of Ukraine

\begin{tabular}{l|l} 
Last name, first name, patronymic & \\
\hline Position & \\
\hline Faculty & \\
\hline Course &
\end{tabular}


Arab World English Journal (AWEJ) Volume 12. Number 2. June 2021

English Linguistic Competencies Formation Karpushyna, Bloshchynskyi, Shumylo, Isaieva, \& Mysechko

\begin{tabular}{|l|l|}
\hline Practical training goal & \\
\hline Division, where practical training took place & from__a year no. \\
\hline Duration of practical training & $\begin{array}{l}\text { Briefly indicate the completeness of carrying out the tasks } \\
\text { and individual plan, the results obtained, the positive aspects } \\
\text { of practical training, the pith and marrow of difficulties and } \\
\text { problems that arose during practical training, suggestions for } \\
\text { further improvement of the organization and procedure for } \\
\text { conducting practical training }\end{array}$ \\
\hline Results of practical training (filled in by the cadet & \\
\hline $\begin{array}{l}\text { Recommendations concerning practical training } \\
\text { results implementation (filled in by the Head of } \\
\text { practical training from the DICBRW) }\end{array}$ & \\
\hline Signature &
\end{tabular}

\section{Methods}

Today's border checks and border surveillance require border guards to be skilled in performing diverse tasks in an efficient manner. A performance improvement tool is needed to prepare future officers for an expected level of performance. Practical training in the would-be positions should be such a tool.

To identify the training needs, content analysis has been performed. It involved analysis of documents, laws, procedures used on the job; moreover, experienced officers (academy's graduates) and instructors of Border Checks and Border Surveillance Departments were interviewed to determine the service content. The information from Decree on education standards by specialty 035 Philology for the first (Bachelor's) level of higher education established by the Ministry of Education and Science of Ukraine has been counted in order not to conflict or contradict job requirements.

This analysis has given us the conception about what knowledge or information is used on this job and what performance gaps the academy's graduates have challenged.

\section{Procedure}

Following the purpose of practical training, it is expected that the third year cadets will acquire a variety of practical knowledge, practice their theoretical knowledge, test out it in reallife situations, and get acquainted with challenges as an interpreter/translator. This knowledge includes:

- Purpose, structure, and functions of the DICBRW;

- Job responsibilities, rights, organization of service activities of an interpreter/translator of the DICBRW; DICBRW;

- Regulatory documents governing the interpreter's/translator's activities of the

- Composition of Border Representative apparatuses of their own state border protection body and a neighboring state's one;

- Peculiarities of organizing and conducting border representative meetings, the role and place of an interpreter/translator at them, norms of ethical behavior; 

meetings;

- Requirements for drawing up protocols based on the results of border representative

- Requirements for the translation of letters, telegrams, facsimile messages, and other documents received by the border guard detachment from the related parties, and the procedure for communicating their content to the parties concerned;

- Translation principles, methods, transformations, and features of their application in the performance of oral and written translations;

- Functional-stylistic and lexical-semantic features of the materials used by the interpreter/translator of the DICBRW;

- Specific border and law enforcement vocabulary, as well as the most commonly used abbreviations that occur in documents and frequently used during international cooperation activities at the level of the border and representative apparatus of the border guard detachment;

- Methods and ways of consecutive translation (paraphrasing, generalizing, extracting, using ready-made clichés).

Even though knowledge is a necessary result, but not sufficient enough at the present stage of social development, as it does not ensure the cadet's readiness for autonomous activity. Only skills can operate knowledge in solving problems. Therefore, it is expected that during the practical training, the cadets will develop the required skills. They embrace:

- Performing oral and written translation, annotate texts, messages on the organization of border protection, and border-representative cooperation from a foreign language to Ukrainian and from Ukrainian to a foreign language;

- Based on translation analysis determining a satisfactory translation strategy;

- Applying various translation methods, techniques, and transformations;

- Evaluating and choosing language tools in the translation process (taking into account the peculiarities of language systems, language norms, and usages);

- Identifying terms in the original text and selecting their terminological equivalents;

- Analyzing translation results from the point of view of informational, normativelinguistic, and stylistic adequacy;

- Editing translation materials inclusive of detected errors;

- Using special dictionaries, reference books, and taking advantage of modern information technologies in translation activities;

- Demonstrating well-timed nonverbal behavior during live meetings, including eye contact with the audience at the meeting, facial expressions, gestures, etc.

Cadets will also be acquainted with

- Organization and structure of the state border protection body;

- International agreements, laws of Ukraine, resolutions of the Cabinet of Ministers of Ukraine, State Border Guard Service orders regulating the activities of the state border protection body in the area of responsibility;

- Specifics of the organization of State Border Protection issues in the area of responsibility of the state border protection body as well as border control performance;

- Assessment of the practical training results in the relevant position by the officials of the state border protection body and the supervisor of practical training from the DICBRW. 


\section{Findings}

One of the ways to update the education's content and technologies, to harmonize them with modern needs, and integrate them into the world educational space is a systematic analysis of the situation at the border and adjusting the content of academic subjects to recent requirements of professional activity and syllabuses orientation towards a competence and competencies-based approach as well as the creation of the effective mechanisms for its implementation. According to many experts (Larsen et al., 2009; Hasbullah \& Sulaiman, 2002; Woon, Abd Karim \& Johl, 2007), competencies are indicators that allow us to determine the readiness of graduates for professional activities, their further personal development, and for active participation in society's life.

Human resources are the most significant and costly investments for the State Border Guard Service of Ukraine. Risks can be extremely high, the cost of poor readiness and low commitment can have an irreparable impact on the service image, and even state security may be put at stake. That is why a competence and competency-based approach to the training process of future professionals can help the State Border Guard Service of Ukraine make it a significant and successful investment.

Competencies measure a person's appropriateness for a particular job. In the case of border guards, who are trained to be translators/interpreters in special divisions, apart from competencies in linguistics, they are expected to perform competencies in interaction and culture awareness. Together they three make up the integrated competence of a border guard, who studies by specialty 035 Philology.

Following the requirements of the position that cadets are to fulfill after graduation from the academy, during practical training, they have to acquire skills that ensure the formation of their competencies specified in the Philology Degree Program. Among them, there are personal competencies, or as they are also called personal attributes, which do not affect any specific job duties but exert influence on the performance quality required by the position. These include aptitudes to:

- $\quad$ Be critical and self-critical;

- $\quad$ Learn and master functional knowledge;

- $\quad$ Search, process, and analyze information from various sources;

- $\quad$ Identify, pose, and solve problems;

- Work in a team and autonomously;

- Communicate in a foreign language in professional activities, study professional literature in a foreign language;

- $\quad$ Develop constructive thinking, analysis, and synthesis;

- $\quad$ Apply knowledge in practical situations;

- Use information and communication technologies, in particular for solving standard tasks of the professional activity.

Technical or professional competencies relate to the knowledge and skills necessary to perform the duties stipulated by the position, for example, translating a telegram within the 
established time limit and communicating its content to the DICBRW authority. These competencies cover the abilities to:

- Use knowledge of the language as a specific sign system, its nature, and functions, registers;

- $\quad$ Use knowledge of the theory and history of the language being studied;

- $\quad$ Analyze dialect and social varieties of the language being studied, and describe the sociolingual situation;

- $\quad$ Freely, flexibly, and effectively use the language being studied in oral and written form, in various genre-style varieties and registers of communication (official, unofficial, neutral), to solve problems in all spheres of life;

- Collect and analyze, systematize and interpret linguistic and literary facts, interpret and translate texts;

- $\quad$ Freely use specific terminology to solve professional problems;

- $\quad$ Be aware of the basics and technologies of creating texts of diverse genres and styles in the national and foreign languages;

- $\quad$ Carry out linguistic, literary, and special philological analysis of texts of different styles and genres;

- $\quad$ Organize corporate communication;

- $\quad$ Use the necessary expressions of speech etiquette in everyday and professional situations, communicate in the national and foreign languages, both orally and in writing;

- Apply the acquired skills of translating, reviewing, and annotating texts of the law-enforcement areas in practical activities.

However, the integrated competence lies in the ability to solve sophisticated specialized tasks in the field of philology (linguistics, translation) in the course of professional activity or training, which involves the use of theories and methods of philological science, and is characterized by the complexity and uncertainty of conditions.

When the personal and professional competencies of future border guards-philologists match with the requirements of their positions, it means that the chosen strategy of cadets' professional training falls in line with their future responsibilities. At the same time, the analysis of the on-the-job training results can help identify gaps in the knowledge and skills that cadets experience at the National Academy or in the course of training. The condition of the practical training program completion is satisfied when the cadets achieve the Program learning outcomes, including the abilities to:

- $\quad$ Freely communicate on professional issues with specialists and non-specialists in the national and foreign languages orally and in writing, use them to organize effective crosscultural communication;

- Work effectively with information: select the necessary information from various sources, critically analyze and interpret it, organize, classify and systematize it;

- $\quad$ Adjust the process of their training and self-education;

- Collaborate with colleagues, representatives of other cultures and religions, supporters of different political views, and so on;

- Use information and communication technologies, in particular for solving standard tasks of the future professional activity; 
- $\quad$ Analyze dialect and social varieties of the language being studied, and describe the sociolingual situation;

- $\quad$ Know the principles, technologies, and techniques of composing oral and written texts of various genres and styles in the national and foreign languages;

- $\quad$ Know the norms of the literary language and be able to apply them in practice;

- $\quad$ Freely, flexibly, and effectively use the language being studied in oral and written forms, in various genre-style varieties and registers of communication (official, unofficial, neutral), to solve problems in all spheres of life;

- Know professional terminology, develop modern critical, autonomous thinking, recognize social codes of behavior and customs that are generally accepted in different societies and environments, interact with representatives of various state structures and demonstrate solidarity and interest in solving problems of local and national significance;

situations;

Use the necessary expressions of speech etiquette in everyday and professional

- Apply translation skills when performing practical tasks, abstract and annotate texts of the law-enforcement context, perform translation.

\section{Discussion}

The education of a cadet studying by specialty 035 Philology is aimed at training a specialist, who meets such qualification characteristics as knowledge of professional-oriented subjects, knowledge of professional technology, including the ability to mobilize knowledge and skills to solve specific professional problems, and the ability to cooperate with colleagues. The graduates are also expected to be highly professional, competent, and ready for highperformance activities in the translation area within the limits of their service duties.

To successfully conduct practical training, the cadets should study the practical training (practice) program before leaving the National Academy. Then, upon arrival at their destination, cadets have to introduce themselves to the Head of the unit and report on the tasks and practical training program. They also ought to study the Division schedule, its mission, and daily routine. Based on the practical training program, cadets draw up an individual working plan for the entire period of practice and submit it for approval to the Head of the division. During the practice, the cadets must plan their work; efficiently conduct each of the events, conscientiously perform all service assignments; keep daily records of the events carried out; be disciplined and impeccable in their uniform and behavior; cherish the honor of the National Academy. Guided by the program and individual task (Appendix A), a cadet draws up a plan for practical training, and their supervisor decides on its approval.

Upon on-the-job training completion, a cadet receives a division supervisor's evaluation statement based on its results. Next to the arrival at the academy, cadets should be present the results of practical training in front of the experts' board (commission) within the period determined by the Rector's order.

In addition to the academic staff of the relevant department and faculty of the Academy, representatives of the State Border Guard Service Administration, regional departments of the 
State Border Guard Service, and the State Border Protection Bodies may be involved in the work of the commission.

For the defense of the reports, the cadets submit a statement, a diary (Appendix B) of practical training, and an individual training plan.

The Commission assesses the presented reports based on a previous study of the cadets' accounting documents, including evaluation statement from the division, their oral reports, and answers to additional questions within the scope of the service duties they had performed during the on-the-job training.

Assessment of practical training takes into account the completeness and quality of the implementation of an individual plan; the performance results of the service duties; the performance quality during practical training; the ability to apply theoretical knowledge and the level of skills acquisition for independent performance of tasks in the process of practical training; the content and quality of reporting documents execution; the cadet's compliance with a disciplinary record.

Those cadets who failed to achieve the results stipulated in the training program and received a negative resolution on their training or an unsatisfactory assessment during the defense stage, the Rector decides on re-passing it in the structural units of the Academy during their vacation. The duration of repeated practical training should ensure the implementation of the curriculum and the mandatory provision of annual vacation leave by the requirements of Part 6 of Article 10 of the law of Ukraine "On social and legal protection of military personnel and members of their families". After completing the practice for a second time, the repeated defense stage occurs. In case of repeated non-fulfillment of the practical training program, receiving a negative resolution on it, or unsatisfactory assessment during the defense of the practice cadets are expelled from the Academy following the procedure established by law.

Cadets who have not defended the results of practical training within the established time limit for valid reasons (illness, family circumstances), by the decision of the Head of the faculty (in agreement with the Head of the Educational Department of the Academy), set an extra time limit for conducting the defense.

\section{Conclusion}

The problem is considered precisely in the light of competence and competencies-based approach. The demands, which the State Border Guard Service makes towards the training of future border guards by 035 Philology specialty, are also sensibly considered in the course of practice.

The value of the professional growth of the future border guard's personality and the development of their professional abilities makes up the professional competence that a cadet acquires during training. It includes their ability to successfully perform professional tasks and duties as an interpreter/translator of the DICBRW. The competence and competencies-based approaches have been studied and applied by the faculty instructors at the request of the SBGS Administration because there is evidence of lower qualification levels of the National Academy 
graduates. The drawbacks include failures to interact with people, work in a team, find the necessary information, and use it in solving problems, accomplish relevant translations for the SBGS and its website, in particular.

Therefore, improving the quality of the educational process at the academy on the issues of approaching the theoretical and practical training of the cadets to perform duties in their primary positions challenges the Foreign Languages Department academic staff enormously. The training outcomes have given the faculty staff an array of ideas on improving classes and educational materials content. In addition, the practical competence of the academic staff has to correspond to the current requirements concerning the organization of operational and service activities at the state border to support the overall level of knowledge, practical skills, and aptitudes of the academy's future graduates.

\section{Suggestions for Further Research}

The methodological implications of establishing English linguistic competencies practical training for future border-guards may offer relevant ideas for further research and at the same time be a helping hand for the faculty to enhance both theoretical and practical training of the cadets. Our further research will concern the issue of eliminating drawbacks in the academic education at the academy and make the training fail-safe as much as possible. Another interest will comprise competencies that necessary to identify knowledge and skills gaps and draft a new provision plan to meet the identified needs.

\section{About the Authors:}

Maiia Karpushyna is a $\mathrm{PhD}$, an associate professor of the Foreign Languages Department at Bohdan Khmelnytskyi National Academy of the State Border Guard Service of Ukraine. Her research interests include teaching English as a second language, problem-based learning and teaching, comparative grammar, English for special purposes. (ORCID ID: https://orcid.org/0000-0002-9480-0070).

Ihor Bloshchynskyi is a Doctor of Pedagogical Sciences, Professor, Head of the Foreign Languages Department, Bohdan Khmelnytskyi National Academy of the State Border Guard Service of Ukraine. His research interests concern English for special purposes, distance learning, military translation. He has more than 200 published papers, including 11 textbooks and manuals. (ORCID ID: orcid.org/0000-0003-1925-9621).

Ivanna Shumylo is a senior lecturer of the Foreign Languages Department at Bohdan Khmelnytskyi National Academy of the State Border Guard Service of Ukraine. Her research interests relate to digital learning, English for professional purposes and terminology. (ORCID ID: orcid.org/0000-0001-9629-8793).

Ilona Isaieva is a senior lecturer of the Foreign Languages Department at Bohdan Khmelnytskyi National Academy of the State Border Guard Service of Ukraine. Her main professional interests are task-based learning, interactive learning, and translation teaching methodologies. (ORCID ID: orcid.org/0000-0002-3936-9468). 
Olha Mysechko is a $\mathrm{PhD}$, professor of the Foreign Languages Department at Bohdan Khmelnytskyi National Academy of the State Border Guard Service of Ukraine. Her research interests concern English for special purposes, special translation teaching and theory of communication. (ORCID ID: orcid.org/0000-0003-4667-6252).

\section{References}

Bloshchynskyi, I. H. (2017). Usage of Anki specialised program application during future Border Guard officers' independent foreign language professional training for passing state examination. Information technologies and learning tools, 58(2), 49-58. DOI: https://doi.org/10.33407/ittt.v58i2.1605

Bloshchynskyi, I. H., Halus, O. M., Pochekalin, I. M., \& Taushan, D. V. (2018). Use of electronic educational and methodological software packages for improving the preparation of future bachelors of philology. Information technologies and learning tools, 66(4), 105-121. DOI: https://doi.org/10.33407/itlt.v66i4.2327

Ceker, E., \& Ozdamli, F. (2016). Features and characteristics of problem based learning. Cypriot Journal of Educational Science, 11(4), 195-202. https://doi.org/10.18844/cjes.v11i4.1296

Hasbullah, H., \& Sulaiman, S. (2002). Industrial internship programme at Universiti Teknologi Petronas - a collaboration strategy that enhanced students' soft skills in the ever-changing technology. Proceedings of International Conference on Engineering Education, August 18- 21, Manchester, U.K, pp. 1-5.

Karpushyna, M., et al., (2019). Warm-Up as a Means of Fostering Target-Language Performance in a Particular English Class. Revista Romaneasca pentru Educatie Multidimensionala, 11(2), 141-159. doi:10.18662/rrem/122

Karpushyna, M. (2018). Theoretical Foundations of Students' Problem-based Learning Technology in the Establishments of Higher Education. Pedagogical Discourse, (24), 5056. https://doi.org/10.31475/ped.dys.2018.24.07

Larsen, P. G. et al. (2009). A multidisciplinary engineering summer school in an industrial setting. European Journal of Engineering Education, 34(6), 511-526.

Makarenko A. S. (1973). Pedagogical poem "Soviet school", Kyiv, 503 p., p. 203

Melnychuk I., Rebukha L., Zavgorodnia T., \& Bloshchynskyi I. (2018). Strategic Significance of English in Self-Education of the Students of Socio-humanitarian Specialities for Fundamentalization of University Education. Modern Journal of Language Teaching Methods, 8(11), 712-720.

Melnychuk, I. et al. (2019). Organization of distance learning on "Nursing" specialty: methodological and legal aspects. International Journal of Applied Exercise Physiology, 8(3/1), 56-65. Doi: 10.26655/IJAEP.2019.10.1

Montessori, M. (2019). From Childhood to Adolescence. Collection of Published Fragments of Books by M. Montessori, (Montessori series Book 12) // Kindle Edition, 107 p.

Omar, M.Z., et al., (2008). Employers' evaluation on attributes obtained during industrial training. Proceedings of the 7th WSEAS International Conference on Education and Educational Technology (EDU'08), 259-263

Order of the Ministry of Education and Science on standard approval of higher education in specialty 035 "Philology" for the first (Bachelor's) level of higher education. Available at https://mon.gov.ua/storage/app/media/vishchaosvita/zatverdzeni\%20standarty/2019/06/25/035-filologiya-bakalavr.pdf 
Sukhomlinskii V. A., (1963). Moral Ideal of the Young Generation / V. A. Sukhomlinskii. Moscow, Publishing House: APN RSFSR

Tang, S., et al., (2020) A Comparative Study of Problem-Based Learning and Traditional Approaches in College English Classrooms: Analyzing Pedagogical Behaviors Via Classroom Observation. Behavioral Sciences, 10, p. 105. https://doi.org/10.3390/bs10060105

The law of Ukraine On social and legal issues. (1991). Available at rada.gov.ua

Theall, M. (2012). Related course material to real-life situations. Available at https://www.ideaedu.org/idea-notes-on-instruction/related-course-material-to-real-lifesituations/

Woon, L.F., Abd Karim, Z.A., \& Johl, S.K. (2007). Examining a successful industrial training program model: inter-relationship among the three main stakeholders: student, university and host company. Proceeding of the 2nd Regional Conference on Engineering Education (RCEE), pp. 24-30. Available at https://www.researchgate.net/publication/267792818_Examining_a_Successful_Industria 1_Training_Program_Model_Interrelationship_Among_the_Three_Main_Stakeholders_Students_University_and_Host_Co mpanies

List of possible individual tasks

\section{Appendix A}

\begin{tabular}{|c|c|}
\hline Ser.No & Task \\
\hline 1 & Ethics of interpreter's behavior during borderline representative meetings \\
\hline 2 & Translator's corporate etiquette \\
\hline 3 & Peculiarities of translating official correspondence \\
\hline 4 & Types of Protocol events and translation \\
\hline 5 & Interpretation with or without notes \\
\hline 6 & Translation cursive \\
\hline 7 & Official two-way translation \\
\hline 8 & Sight Interpretation \\
\hline 9 & Abstract translation \\
\hline 10 & Sequential translation \\
\hline 11 & Requirements for making written translations \\
\hline 12 & Components of interpreter's skills \\
\hline 13 & Psychological aspects of translation \\
\hline 14 & Translation and cross-cultural communication \\
\hline 15 & Modern translation quality standards and their implementation \\
\hline 16 & Modern criteria for checking the adequacy / accuracy of translation \\
\hline 17 & Interpretation and translation: shared and different features \\
\hline 18 & Term and its properties \\
\hline 19 & Types of terminological units \\
\hline 20 & Institutional term systems \\
\hline 21 & Typology of translation types \\
\hline 22 & Translation tools to achieve adequacy \\
\hline 23 & Individual translator's style and adequacy \\
\hline 24 & Machine translation capabilities and prospects \\
\hline 25 & Terminological aspects of translation \\
\hline 26 & Professional language and translation \\
\hline 27 & Professional competence of a translator and its components \\
\hline 28 & Equivalence and adequacy of translation \\
\hline
\end{tabular}


Arab World English Journal (AWEJ) Volume 12. Number 2. June 2021

English Linguistic Competencies Formation Karpushyna, Bloshchynskyi, Shumylo, Isaieva, \& Mysechko

\begin{tabular}{|c|l|}
\hline Ser.No & \multicolumn{1}{c}{ Task } \\
\hline 29 & Cognitive translation strategies \\
\hline 30 & Reasons of difficulties in the translation process \\
\hline 31 & Translation difficulties and barriers \\
\hline 32 & Methods and ways of professional sequential translation \\
\hline 33 & Aspects of translator's nonverbal communication \\
\hline
\end{tabular}

\section{Appendix B}

\section{Practical training diary}

\section{PRACTICAL TRAINING}

DIARY

of the cadet

(rank, first name, last name)

faculty

Head of practical training from the Academy course, _ group

Place of practical training

(position, rank, first and last name)

Practical training in the position

(name of the division)

Duration of practical training

in the period from

to

$$
\text { (position) }
$$
20

I. General instructions

II. Tasks specified by the practical training program

III. Cadet's duties during training and practical training realization

IV. Comments / remarks

V. Practical training accounting card

(records are kept daily throughout the entire period of practical training)

\begin{tabular}{|l|l|l|}
\hline Date & Time & List of classes, tasks, and events \\
\hline & & \\
\hline & & \\
\hline
\end{tabular}

VI. Records of practical training results

(filled in by the Head of practical training from the division)

Cadet of _ group 